高分子論文集 (Kobunshi Ronbunshu), Vol. 45, No. 6, pp. 531-534 (June, 1988)

\title{
GPC 法による液晶性芳香族ポリエステルの分子量分布の測定
}

\author{
絹川 明男*1 ・ 黄瀬 善融*1
}

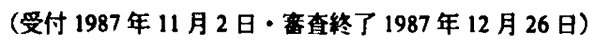

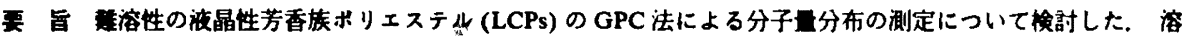
媒として掌温で固体のペンタフルオロフェノール(PFP)を，GPCカラムとしてポリスチレンゲルの充てんされた

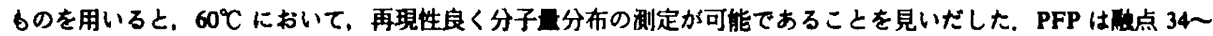
$36^{\circ} \mathrm{C}$ であるため，流路系全体が温度制御可能な装目を試作して用いた，試料の溶解条件、测定条件、GPC-LALLS

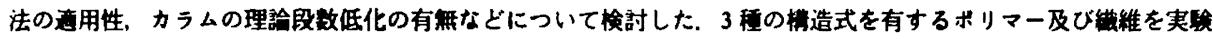
室で試作し、本法を用いて，その分子量分布を明らかにした。
\end{abstract}

\section{1 籍曹}

液晶性芳香族ポリエステル(LCPs) から成るプラス チックスや絰維は、强度、弾性率、而熱性など多くの性 質において，従来のポリェステル䌘品を淩駕するため， 近年その研究開発が活発に行われており,一部のものは すでに生産か開始されている. 柇萫品性についても非常 に徣れており，特殊な試菜を除いて，有機溶媒にはかな り高蕰でも不溶であるため，従来の GPC 法は勿論のこ と、非常に高温での刷定が可能な GPC 法")によっても分 子量分布を测定することは不可能であり，それに関する 文墄は見られない，液晶性芳香族ポリアミト(Kevlar) の GPC 法による分子吾分布の剧定加湛硫酸を用いて行 われた文愺”はあるか，LCPs に対する南用性の可否につ いては明らかにされていない。

特許によると、LCP\&はベンクルオロフェノール

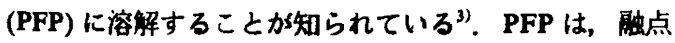

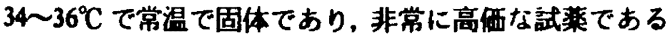
が，流路系のすへてが温度制御可能な装監を試作するこ とは比较的容易であること，使用後の溶媒は蒸留などに より，精製して再使用が可能であること，などが予想さ れた. そこで，著者らは常温で固体の武莱を用いること ができる GPC装置の試作，試料の溶解条件，測定条件。 ポリスチレンゲルカラムの通用性，カラムの理論段数低 化の有無、GPC-LALLS 法の高用性などについて検討し た.

*1（怢)東レリサーチセンター（一520大律市園山 3-2-1）
その結果，LCPs の分子量の分布の副定は PFP とポリ スチレンゲルカラムを用いることにより，60ㄷ において 再現性良く行えることを見いだした。 3 種の LCPsを試 作し，本法を適用して，それらの分子量分布を初めて明 らかにした.

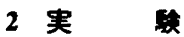

\section{1 試料}

LCPsは LCP-A（pーヒドロキシ安息香酸/2-ヒドロオキ シ-6-ナフトエ酸: $3 / 1$ モル比) $)^{3)}$. LCP-B (p-ヒドロキシ 安息香酸/4,4'-ジヒト゚ロキシジフェニル/テレフタル酸： 4/1/1/モル比) ${ }^{4)}$, LCP-C 䋊維 (p-ヒドロキシ安息香酸/ 4,4'-ジヒト゚ロキシジフェニル/テレフタル酸/インフタル 酸: $16 / 4 / 3 / 1$ モル比) $)^{s)}$ を試作して用いた。

\section{2 侙莫及ひ䒧䓝}

PFP は Aldrich 製を, 単分散ボリスチレンは東ンー (株)製を用いた。

GPC 装是の椿成は510 型ボンプ, U6K インジェク ター, 401 型示差届折率検出器 (RI) (いずれも Waters 社製)，CMX-100 型低角度レーザー光散乱光度計 (LALLS) (Chromatix 社製)、及びカラム : Shodex K-80 M (6.5 mm i.d., $30 \mathrm{~cm}, \mathrm{~L}$.) (昭和電工(株)製) 加成って おり，すへての流路系の温度制御は空気恒温槽，䛻㻴式 ウオーターパス、リボンヒーターなどを用いて行った。 ポンブ及びインジェクターはデッドボリュームを少なく するため, 一部改良した。陚料の示差届折率增分 $(\mathrm{d} n /$ dc) の測定は KMX-16 型レーザー示差屈折率計 (Chromatix 社製 ) を，溶媒の届折率の測定は H-20 型モノク 
組川・黄瀬

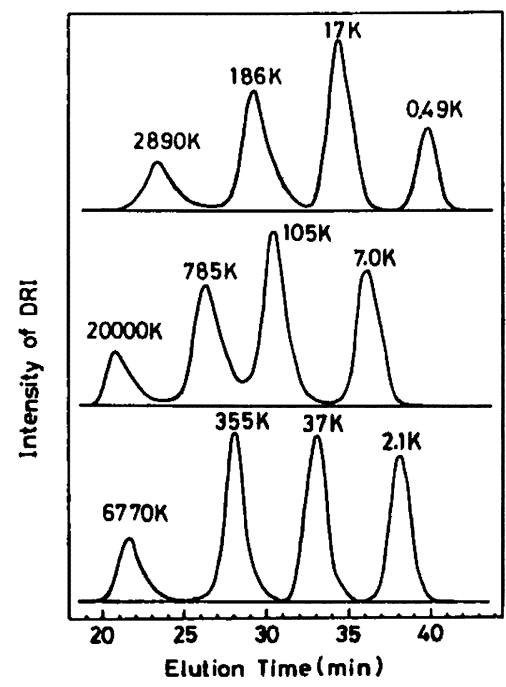

Fig. 1. GPC curves of monodisperse polystyrene. Sample, polystyrene, $c a .0 .04 \%, c a .0 .08 \%$; injection volume, $0.2 \mathrm{~m}$; column, Shodex K-80M(1); solvent, pentafluorophenol; flow rate, $0.3 \mathrm{~m} / / \mathrm{min}$; detector, RI; temperature, $60^{\circ} \mathrm{C}$.

ロメーター(633 nm, Jobin Yvon 社製) 及びアッべ2T 型 屈折率計（アタゴ(社)製）を用いた。

\subsection{GPC 曲線の測定}

塊状の試料 (LCP-A, LCP-B) は約 $0.2 \mathrm{mg}$ 以下の細片 にし，織維試料 (LCP-C) は短く切断した後，それぞれ 3〜5 mg を精秤して, $10 \mathrm{~m} /$ のPPを添加した. 試料の 溶解は後の項で述へるように，それぞれ異なる温度で行 い，0.45 $\mu \mathrm{m}$ フィルターでろ過して，そのろ液を測定溶 液とした。試料溶液の注入吾は $0.2 \mathrm{~m} /$ であり，注入は $60^{\circ} \mathrm{C}$ に保たれたシリンジを用いて行った. カラム温度及 び流路系の温度はすへて $60^{\circ} \mathrm{C}$ に制御して測定した。

\section{3 洁果及ひ考察}

\section{1 式料の溶解}

LCP-A は低温では溶解しにくく，時々かくはんしな からら、約 $100^{\circ} \mathrm{C}$ に保持すると、1〜2時間で溶解した。

LCP-B は約 $60^{\circ} \mathrm{C}$ で溶解可能であり，高温では逆に溶解 性加悪かった。 LCP.C 維維は PFP の沸点 $\left(143^{\circ} \mathrm{C}\right)$ 以下 では膨淍はするものの、いかなる温度でも不溶であった か、ガラス製アンプルに封入した後，オートクレーブ中 で約 $200^{\circ} \mathrm{C}$ に加熱することにより, 溶解可能であった. これらの溶液は $0.45 \mu \mathrm{m}$ のフィルターでろ過可能である こと，及び後の項で述へる分子量分布の測定結果から， 完全に溶解していると推定された．3種の試料のろ過液 は $50 \sim 60^{\circ} \mathrm{C}$ に加温しておくと，その溶解状態を安定に 保つことができる.

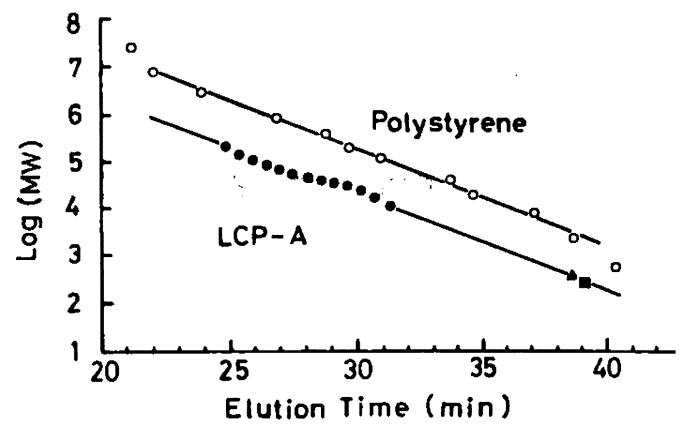

Fig. 2. Calibration curves of polystyene and LCP-A. Sample, polystyrene, LCP-A; injection volume, $0.2 \mathrm{ml}$; column, Shodex K-80M(1); solvent, pentafluorophenol; flow rate, $0.3 \mathrm{ml} / \mathrm{min}$; detector, RI, LALLS; temperature, $60^{\circ} \mathrm{C}$.

\section{2 削定条件}

3.2.1 分䍀カラム ポリスチレンゲルカラム (Shodex K-80M, $6.5 \mathrm{~mm}$ i.d., $30 \mathrm{~cm}$, L.) を用い, PFP に溶媒交換 して, カラムの理論段数及び単分散ポリスチレンの分離 について検討した. カラムの理論段数は 7000 10000 段 (ベンゼン $0.5 \mu l$, PFP 流速 $0.3 \mathrm{~m} / / \mathrm{min}$, 温度 $60^{\circ} \mathrm{C}$ ) を示 し、ビークの対称性も良く、Fig. 1 に示したように単分 散ポリスチレンの分離も良好であった。これらのことか ら，PFPに対してポリスチレンゲルカラムが䧟用できる と判断された。

3.2.2 カラム温度 $40 \sim 70^{\circ} \mathrm{C}$ の温度鉋囲においてカ

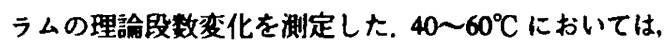
温度の上开とともにカラム効染は著しく上昇するが、こ れはゲルの踣雬と浴媒粘度の低下の両方に起因している と考えられる.60〜 70 C でその上昇カーブがゆるやかに なるが、これはゲルの膨濶が過剩になりはじめているよ

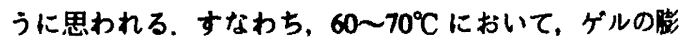
閪状悲は，最適に近くなっていることが推定される。こ の温度籍囲では LCPs の溶液も安定であり, 測定の最適 温度は $60^{\circ} \mathrm{C}$ 付近であると考えられる.

3.2.3 カラムの理諭段数の変化 PFP は室温で個体 であるため，通転時と停止時において，液体と個体の相 変化をくり返すことになる. 相变化は必然的に体積変化 を伴い，1）ゲルの膨潤度变化，2）ゲル細孔の破俵，3）力 ラム全体の変形、などが予想され，その結果として，カ ラムの理論段数低下か照念される. 理論段数 7800 段の カラムを用いて，昇温速度，冷却速度，流速などに注意 して, 液体 $\left(60^{\circ} \mathrm{C}\right)$ と個体 $\left(23^{\circ} \mathrm{C}\right)$ の变化を 10 回くり返 した後の理論段数は約 6500 殷であり, その後は徐々に 低下して約 5000 段でほぼ安定する。このことからボリ スチレンゲルカラムはPFPに対して使用可能であると 判断された。 また，システム全体は個体〜液体（室温〜 


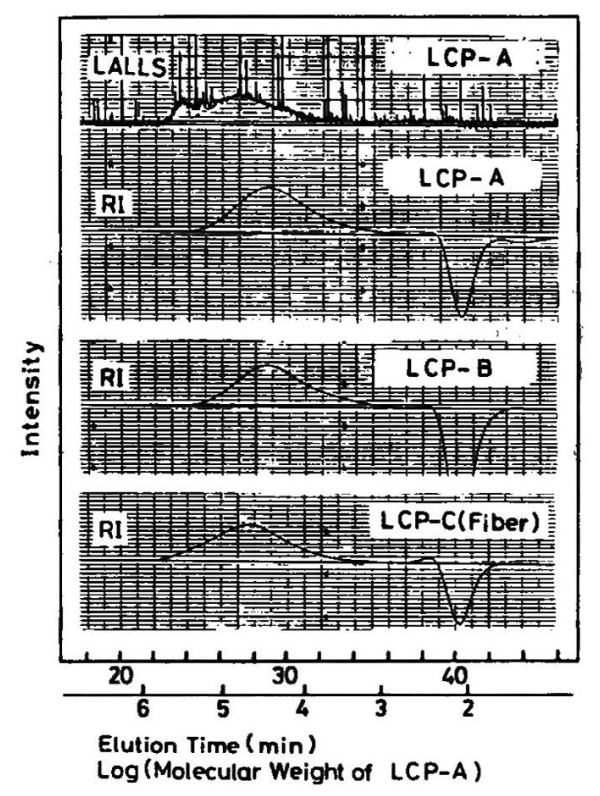

Fig. 3. GPC and GPC-LALLS curves of LCPs. Sample, LCP-A, LCP-B, LCP-C(Fiber); concentration, $0.04 \%$; injection volume, $0.2 \mathrm{ml}$; column, Shodex K-80M(1); solvent, pentafluorophehenol; flow rate, $0.3 \mathrm{~m} / / \mathrm{min}$; detector, RI, LALLS; temperature, $60^{\circ} \mathrm{C}$.

$\left.60^{\circ} \mathrm{C}\right)$ のくり返し使用に対しても破損，液漏れなどの支 障もなく運転できることがかかった。

3.2 .4 試料湿度と注入量 LCP-A の 0.02 0.1\% PFP 溶液を調整し，その $0.2 \mathrm{~m} l$ を注入して GPC曲線形状の 変化を測定した。 ポリスチレンのような届曲性高分子の 場合は濃度約 $0.2 \%$ 以下ではほとんど一定形状の GPC 曲線を与えるか，LCPs の場合は約 $0.05 \%$ 以上では大き な形状変化を示し，実際の測定は $0.04 \%$ 以下（注入量が $0.2 \mathrm{~m} l$ の場合）にする必要があることがわかった。

\section{3 分子量校正曲線}

12 種の単分散ポリスチレンを測定して得られた GPC 曲線 (Fig. 1) のデー夕を基にして作成した校正曲線を Fig. 2 に示した. 一方, LCPs の校正曲線を知るため, LCP-A の GPC-LALLS 测定を行い (Fig. 3), 各溶出時間 の分子量を計算して Fig. 2 中の印の結果を得た。これ らの值と, ジフェニルフタレート（分子量 318, 印）及 びフェニルベンゾエート（分子量 198，回印）の実測点を
直線に近似して, LCP-A の校正曲線 (Fig. 2) を作成し た. PFP の屈折率 $(1.4356)$ 及び届折率濃度変化 $(\mathrm{d} n / \mathrm{d} c$ : $0.212 \mathrm{ml} / \mathrm{g}$ ) (いずれも, $633 \mathrm{~nm}, 60^{\circ} \mathrm{C}$ ) は実則を行い, GPC-LALLS 曲線から分子量値を計算する時に用いた。 この結果から LCPsのような半屈曲性高分子の分子量を ポリスチレンの校正曲線で計算した場合, 真の分子量よ りも，かなり大きい値淂られることがわかる. 分子量 の計算には，第 2 ピリアル㐿数及び光学異方性に対する 補正は考慮されていない，LCP-A に蛍光のないことは， その $0.1 \%$ 溶液を調製して, 励起波長 $633 \mathrm{~nm}$ の営光 ペクトルを測定することにより確認した. Fig. 3 の LALLS 曲線において, 23 分から 25 分の位置に見られ るピークは強度に再現性がないこと, 及び漂度が雾に近 い領域であることから，ゲル微粒子か，カラムのエンド フィルター及び LALLS 直前のラインフィルターの詰り 物などによるものと考えられる. 約 26 分以後の LALLS 曲線には再現性があり，試料ポリマーによる光散乱であ ることは明らかであり，濃度零の領域の光散乱強度を零 とすれば試料による光散乱は点線のようになることが考 えられる. LALLS曲線のノィスが大きいのは溶媒の流 速が低くポンプの脈動による溶媒密度变化によるすのと 考えられる.

\section{4 分子量分布の測定例}

3.1 項に準じて LCP-A， LCP-B，及び LCP-C 織維の $0.04 \%$ 試料溶液を調整し、その $0.2 \mathrm{~m} l$ を注入して GPC 及び GPC-LALLS 曲線の測定を行い, Fig. 3 の結果を得 た. Fig. 3 の横軸は溶出時間及び LCP-A の校正曲線を 用いて計算された分子量値を示した。

LCP-A は分子量約 $7 \times 10^{2}$ から約 $4 \times 10^{5}$ の範囲に広か る分布を有し、主分画分子量は約 $4 \times 10^{4}$ であることが わかった． LCP-B は LCP-A とほぼ等しい分子量分布を 有する．LCP-C 織維は分子量 (LCP-A 相当分子量) 約 $1 \times 10^{3}$ から約 $1 \times 10^{6}$ の範囲に広がる分布を有し, 主分 画分子量は約 $5 \times 10^{4}$ であり, 前 2 者よりも高分子量で あり, かつ, 分布幅が広い。

\section{文献}

1) 組川明男，高分子論文集，44，139 (1987).

2) M. Arpin and C. Strazielle, Polymer, 00, 591 (1977).

3) Celanese, 特開昭 53-128651 (1978).

4) Carborundum, 特開昭 47-47870 (1972).

5) 住友化学, 特開昭 58-121219 (1983). 
[Notes]

Molecular Weight Distribution Measurements of Liquid Crystalline Aromatic Polyeaters by Gel Permeation Chromatography

Akio KInUGawa*1 and Yoshitsugu KISE*1

*1 Toray Research Center (2-1, Sonoyama 3-chome, Otsu, 520 Japan)

A GPC method was developed to measure molecular weight distributions (MWDs) of liquid crystalline aromatic polyesters (LCPs) which can not be dissolved by ordinary organic solvents. The combination of pentafluorophenol (PFP) and polystyrene gel columns was found to give a reproducible GPC curves of LCPs at $60^{\circ} \mathrm{C}$ by using a temperature-controlled instrument made at our laboratory. This GPC method revealed heretofor unrecognized features of the MWDs of LCPs: LCP-A, LCP-B, LCP-C (Fiber). GPC-LALLS method was utilized to make absolute molecular weight calibration curves for LCPs.

KEY WORDS Liquid Crystalline Aromatic Polyesters / GPC / GPC-LALLS / Pentafluorophenol / Polystyrene Gel

Column / Molecular Weight Distribution /

(Received November 2, 1987: Accepted December 26, 1987) [Kobunshi Ronbunshu, 45(6), 531-534 (1988)] 